\title{
Purification and properties of a novel glycosaminoglycan depolymerase from Streptococcus intermedius strain UNS 35
}

\author{
H. SHAIN, K. A. HOMER and D. BEIGHTON \\ Joint Microbiology Research Unit, King's College School of Medicine and Dentistry, Caldecot Road, Denmark \\ Hill, London SE5 9RW
}

\begin{abstract}
A glycosaminoglycan (GAG) depolymerase that acts on chondroitin sulphate A (CS-A), chondroitin sulphate C (CS-C) and hyaluronic acid (HA) was purified to apparent homogeneity from a culture of Streptococcus intermedius, strain UNS 35, grown in minimal medium supplemented with CS-A as the sole carbon source. The enzyme was purified by ammonium sulphate precipitation followed by serial chromatography on DEAE Trisacryl M, CM Trisacryl $M$ and heparin-agarose. SDS-PAGE analysis of the purified enzyme yielded a single band with a mol.wt of $c$. 83000 . The purified GAG depolymerase was unusual in its substrate specificity. The enzyme was initially regarded as a CS depolymerase because of its induction by CS-A. However, the GAG depolymerase exhibited greatest activity against $\mathrm{HA}$, whereas the degradation rates of CS-A and CS-C were $c$. $8 \%$ and $2 \%$, respectively, of the rate with HA. On this basis the enzyme could be classified as a hyaluronidase rather than a CS depolymerase. The pH optimum was around neutrality and the enzyme was unusual in having a high pl of approximately 9.3 .
\end{abstract}

\section{Introduction}

The isolation of 'Streptococcus milleri' from human clinical specimens has become almost synonymous with the diagnosis of deep-seated sepsis [1-4] and other workers have suggested that ' $S$. milleri' bacteraemia in a febrile patient should prompt a search for an internal abscess $[5,6]$. These bacteria are often not recognised as pathogens $[7,8]$ primarily because of confusion over nomenclature and difficulties in routine laboratory identification. Recently, Whiley and Beighton stated that members of the 'S. milleri' group represented three distinct species, namely $S$. intermedius, $S$. constellatus and $S$. anginosus, and demonstrated simple laboratory tests for their differentiation [9].

The propensity of these organisms for causing serious pyogenic infections is well documented, but the factors mediating their pathogenicity and ability to proliferate in vivo are still unclear. One possible mechanism may be the production of extracellular enzymes that degrade host tissue components $[7,8,10]$. These

Received 4 Oct. 1995; accepted 9 Oct. 1995.

Corresponding author: Dr H. Shain enzymes may contribute not only to the pathogenic potential of these organisms but also fulfil an important nutritional role. Of the ' $S$. milleri' group, $S$. intermedius is particularly associated with brain and liver abscesses [11, 12] and produces a greater range of glycoprotein- and glycosaminoglycan- (GAG) degrading enzymes, including hyaluronidase and chondroitin sulphate (CS) depolymerase, than any other species of viridans streptococci [13]. GAGs are linear polysaccharides composed of repeating disaccharide units and include chondroitin sulphate A (CSA), chondroitin sulphate C (CS-C), dermatan sulphate, keratan sulphate, heparan sulphate, heparin and hyaluronate, important components of the extracellular matrix responsible for the structural integrity of host tissue [14].

We have demonstrated recently that the growth of $S$. intermedius strain UNS 35 , in minimal medium supplemented with $\mathrm{CS}-\mathrm{A}$ as the sole carbohydrate source, results in the production of extracellular CS depolymerase and sulphatase activities [39]. The CS depolymerase enzyme produced by $S$. intermedius has not been purified previously to homogeneity nor have its biochemical properties been reported. This paper describes the purification and characterisation of the CS depolymerase activity from an $S$. intermedius strain. 


\section{Materials and methods}

\section{Bacterial strain and culture}

$S$. intermedius strain UNS 35 , first isolated by Professor P. F. Unsworth from a human brain abscess, was obtained from the Central Public Health Laboratory, 61 Colindale Avenue, London, and was stored frozen on glass beads at $-70^{\circ} \mathrm{C}$. Bacteria were maintained by routine subculture on Fastidious Anaerobe Agar (Lab M Ltd, Lancs) containing defibrinated horse blood $5 \% \mathrm{v} / \mathrm{v}$ (FAA) in an anaerobic cabinet (Don Whitley, Shipley, West Yorkshire) for $48 \mathrm{~h}$ at $37^{\circ} \mathrm{C}$.

\section{Assay of reducing terminal $\mathrm{N}$-acetylhexosamine for measurement of CS depolymerase activity}

CS depolymerase activity at different stages of the enzyme purification was determined by measuring the increase in $\mathrm{N}$-acetylhexosamine concentration after the method of Levvy and McAllan [15], with either CS-A (Sigma) or CS-C (Sigma) as substrate. A $20-\mu 1$ sample of enzyme preparation was added to $62.5 \mu \mathrm{l}$ of substrate $(20 \mathrm{mg} / \mathrm{ml})$ and $42.5 \mu \mathrm{l}$ of $0.2 \mathrm{M}$ Tris- $\mathrm{HCl}$ or $0.2 \mathrm{M}$ sodium phosphate buffer, $\mathrm{pH} 7.5$, and incubated for $18 \mathrm{~h}$ at $37^{\circ} \mathrm{C}$. Twenty $\mu \mathrm{l}$ of $0.2 \mathrm{M}$ potassium borate were added to $62.5 \mu 1$ of the reaction mixture and the assay was heated at $100^{\circ} \mathrm{C}$ for $3 \mathrm{~min}$. After cooling to ambient temperature, $375 \mu \mathrm{l}$ of $\mathrm{N}$-acetylhexosamine reagent [16] were added to each sample and these were incubated for $20 \mathrm{~min}$ at $37^{\circ} \mathrm{C}$. Portions $(200 \mu \mathrm{l})$ of each sample were dispensed into 96-well microtitration trays and the absorbance at $540 \mathrm{~nm}$ was recorded with a plate-reading spectrophotometer (Titertek, Multiscan MCC 340; ICN-Flow Laboratories Ltd, Herts). The increase in reducing $\mathrm{N}$-acetylgalactosamine was estimated by comparison with $\mathrm{N}$-acetylgalactosamine standards $(0-10 \mathrm{mM})$ treated in the same manner. Commercial CS-A contained CS-A (sulphated at the 4-position of the $\mathrm{N}$-acetylgalactosamine residue) $70 \%$ and CS-C (sulphated at the 6-position of the Nacetylgalactosamine residue) $30 \%$; CS-C contained CSA $10 \%$ and CS-C $90 \%$. The choice of substrate (CS-A or CS-C) and buffer $(0.2 \mathrm{M}$ Tris- $\mathrm{HCl}, \mathrm{pH} 7.5$, or $0.2 \mathrm{M}$ sodium phosphate, $\mathrm{pH} 7.5$ ) used in the assay for enzyme activity depended on the stage of enzyme purification.

\section{Assay of 4,5-unsaturated disaccharide formation for measurement of CS depolymerase activity}

For the determination of $\mathrm{pH}$ optima, $\mathrm{K}_{\mathrm{m}}, \mathrm{V}_{\max }$ and substrate specificity, enzyme activity was assayed by a modification of the method of Saito et al. [17]. Enzyme preparation $(20 \mu \mathrm{l})$ was added to $50 \mu \mathrm{l}$ of the appropriate buffer and $70 \mu \mathrm{l}$ of substrate solution and incubated at $37^{\circ} \mathrm{C}$. The reactions were stopped after an appropriate incubation period by heating at $100^{\circ} \mathrm{C}$ for $5 \mathrm{~min} ; 40 \mu \mathrm{l}$ of the reaction mixture were added to $10 \mu 1$ of enriched Tris buffer, $\mathrm{pH} 8.0$, and incubated at $37^{\circ} \mathrm{C}$ for $30 \mathrm{~min}$. Then $950 \mu \mathrm{l}$ of $0.1 \mathrm{M} \mathrm{HCl}$ were added to each sample and, after centrifugation $(13000 \mathrm{rpm}$, $10 \mathrm{~min}$ ), the absorbance at $232 \mathrm{~nm}$ was measured (Shimadzu UV 160-A recording spectrophotometer) with quartz cuvettes. Control assays contained heatinactivated $\left(100^{\circ} \mathrm{C}\right.$ for $\left.10 \mathrm{~min}\right)$ enzyme preparation. The concentration of unsaturated disaccharide formed in each assay was calculated from the increase in absorbance in conjunction with the use of 5.7, 5.1 and 5.5 as millimolar absorbance coefficients for $\triangle \mathrm{UA}$ GalNAc-OS (2-acetamido-2-deoxy-3-O-( $\beta$-Dgluco-4- $\Delta$ enepyranosyluronic acid)-D-galactose), $\Delta U A$ GalNAc-4S (2-acetamido-2-deoxy-3-O-( $\beta$-D-gluco-4$\Delta$ enepyranosyluronic acid)-4-O-sulpho-D-galactose) and $\triangle \mathrm{UA}$ GalNAc-6S (2-acetamido-2-deoxy-3-O$(\beta$-D-gluco-4- $\Delta$ enepyranosyluronic acid)-6-O-sulpho-Dgalactose), respectively [18].

\section{Growth of bacteria for CS depolymerase production}

Preparations of CS depolymerase for purification and characterisation were obtained from $25 \mathrm{~L}(5 \times 5$-L volumes) of a semi-defined medium (CasMM) $[16,19]$ supplemented with CS-A $5 \mathrm{mg} / \mathrm{ml}$ as the sole source of carbohydrate. Each $5 \mathrm{~L}$ of CS-A-supplemented CasMM was inoculated with $250 \mathrm{ml}$ of a late exponential phase culture of $S$. intermedius UNS 35, grown in Brain Heart Infusion Broth (BHI; Oxoid) and incubated anaerobically at $37^{\circ} \mathrm{C}$ with constant stirring for $18 \mathrm{~h}$. Cells were harvested by centrifugation $(10000 \mathrm{rpm}$, $20 \mathrm{~min}, 4^{\circ} \mathrm{C}$ ) and the culture supernates were decanted for purification of the CS depolymerase.

\section{Concentration of culture supernate and ammonium sulphate precipitation}

The culture supernate $(25 \mathrm{~L})$ was concentrated 16-fold to $c .1 .5 \mathrm{~L}$ by ultrafiltration (Ultrasette ultrafiltration unit, $10 \mathrm{kDa}$ cut-off; Flowgen, Sittingbourne, Kent). The proteins were precipitated by the gradual addition, with gentle stirring, of ammonium sulphate to $80 \%$ saturation at $4^{\circ} \mathrm{C}$. After $18 \mathrm{~h}$ the precipitate was pelleted by centrifugation $\left(15000 \mathrm{rpm}, 1 \mathrm{~h} 4^{\circ} \mathrm{C}\right)$, dissolved in a minimal volume of ice-cold $50 \mathrm{mM}$ Tris-HCl buffer, pH7.5 (Tris-buffer) and dialysed against three changes of the same buffer at $4^{\circ} \mathrm{C}$. The dialysate was divided into $10-\mathrm{ml}$ volumes and stored at $-20^{\circ} \mathrm{C}$.

\section{Chromatography with diethylaminoethyl (DEAE) trisacryl $M$}

A column $(1.5 \mathrm{~cm} \times 24 \mathrm{~cm})$ of DEAE Trisacryl M (Sepracor SA, Villeneuvre la Garenne Cedex, France) was prepared and equilibrated with $80 \mathrm{ml}$ of Trisbuffer. The dialysed ammonium sulphate fraction (10$\mathrm{ml}$ volumes) was applied to the column at the rate of $40 \mathrm{ml} / \mathrm{h}$. After washing the column with $80 \mathrm{ml}$ of Trisbuffer, a step gradient $(80 \mathrm{ml}$ each of $0.1 \mathrm{M}, 0.2 \mathrm{M}$, 
$0.3 \mathrm{M}$ and $0.4 \mathrm{M} \mathrm{NaCl}$ in Tris-buffer) was used to elute the proteins from the column. Fractions $(8 \mathrm{ml})$ were collected and enzyme activity was monitored by the $\mathrm{N}$ acetylhexosamine assay with CS-A as substrate. The column was regenerated by washing with $40 \mathrm{ml}$ of $1 \mathrm{M}$ $\mathrm{NaCl}$ in Tris-buffer, followed by $40 \mathrm{ml}$ of $0.5 \mathrm{M}$ Tris- $\mathrm{HCl}, \mathrm{pH} 7.5$, and then re-equilibrated with $80 \mathrm{ml}$ of Tris-buffer, before the application of further samples.

Enzyme activity was detected in the effluent from the wash buffer and each of the step gradient buffers used for elution. The fractions with the greatest activity (15-21) eluted at the $0.1 \mathrm{M} \mathrm{NaCl}$ step (Fig. 1) were pooled, desalted (in Tris-buffer) and concen- trated with a stirred cell concentrator (10000 Da cut-off, Flowgen). The fractions containing minor levels of depolymerase activity were not investigated further.

\section{Chromatography with carboxymethyl (CM) trisacryl $M$}

A CM trisacryl M (Sepracor) column $(1.5 \mathrm{~cm} \times 24 \mathrm{~cm})$ was prepared and equilibrated with $80 \mathrm{ml}$ of Trisbuffer. The partially purified and concentrated enzyme fraction $(11 \mathrm{ml})$ from the DEAE trisacryl $\mathrm{M}$ column was applied to the $C M$ trisacryl $M$ column, washed with $80 \mathrm{ml}$ of the Tris-buffer and eluted with a linear gradient of $0-0.5 \mathrm{M} \mathrm{NaCl}$ in Tris-buffer (total volume $200 \mathrm{ml}$ ) at a flow rate of $40 \mathrm{ml} / \mathrm{h}$. The fractions $(8 \mathrm{ml})$ were monitored for enzyme activity by the $\mathrm{N}$ acetylhexosamine assay with CS-A or CS-C as substrate. Active fractions (19-28) were pooled, desalted with exchange of buffer to $50 \mathrm{mM}$ potassium phosphate, $\mathrm{pH} 7.5$, and then concentrated as described previously to $c .750 \mu 1$ (Fig. 2).

\section{Affinity chromatography with heparin-agarose}

Heparin-agarose affinity chromatography was carried out with modifications of a previously described method [20]. The enzyme preparation from the CM trisacryl $M$ column was applied to a heparin-agarose column (Type 1, Sigma; $1.5 \mathrm{~cm} \times 8.5 \mathrm{~cm}$ ), equilibrated with 5 column-volumes of $50 \mathrm{mM}$ potassium phosphate buffer, $\mathrm{pH}$ 7.5. Preliminary experiments indicated that the depolymerase bound only weakly to the heparinagarose column, so to avoid co-elution of the enzyme with non-adsorbed material, the sample was divided and applied to the column in two separate batches. The samples were applied to the column at a flow rate of $17 \mathrm{ml} / \mathrm{h}$ and, after washing with $30 \mathrm{ml}$ of equilibration buffer, the protein was eluted with a gradient of 0 $0.5 \mathrm{M} \mathrm{NaCl}$ in $50 \mathrm{mM}$ potassium phosphate, $\mathrm{pH} 7.5$, in 5 column-volumes. The flow rate was $30 \mathrm{ml} / \mathrm{h}$ and $4-\mathrm{ml}$ fractions were collected.

The column was regenerated between sample applications by washing with up to 20 column-volumes of $0.1 \mathrm{M}$ Tris- $\mathrm{HCl}$ buffer containing $0.5 \mathrm{M} \mathrm{NaCl}, \mathrm{pH} 7.5$, followed by an equal volume of $0.1 \mathrm{M}$ sodium acetate containing $0.5 \mathrm{M} \mathrm{NaCl}, \mathrm{pH} 5.0$, and finally re-equilibrated by washing with 5 column volumes of $50 \mathrm{mM}$ potassium phosphate, $\mathrm{pH} 7.5$. The $\mathrm{N}$-acetylhexosamine assay was used to monitor enzyme activity in the fractions, with CS-C as the substrate. The active fractions (15-19) were pooled, divided in 5-ml volumes and stored at $-20^{\circ} \mathrm{C}$ before further characterisation (Fig. 3).

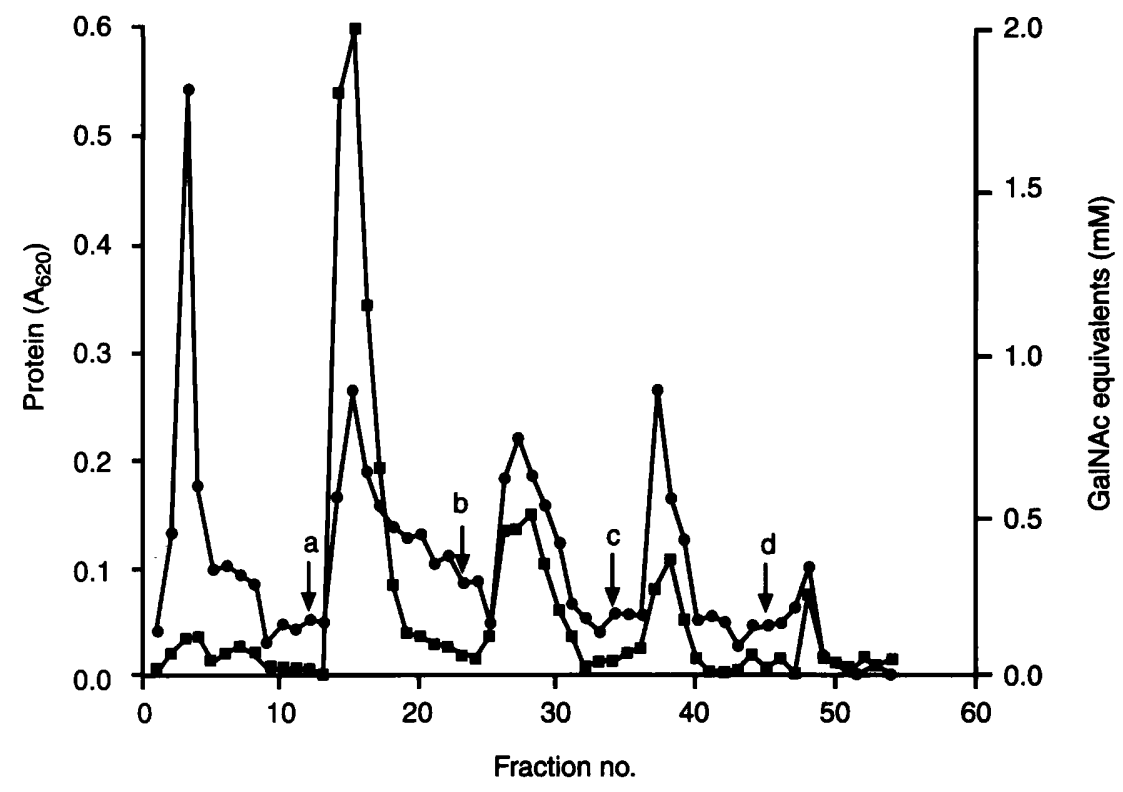

Fig. 1. Separation of GAG depolymerase on a DEAE trisacryl M column $(1.5 \times 24 \mathrm{~cm})$. The first 11 fractions were eluted with $50 \mathrm{mM}$ Tris- $\mathrm{HCl}, \mathrm{pH}$ 7.5. Later fractions were eluted with a step gradient. Arrows (from left to right) indicate changes of elution buffers $(\mathrm{a}, 0.1 \mathrm{M}, \mathrm{b}, 0.2 \mathrm{M} ; \mathrm{c}, 0.3 \mathrm{M} ; \mathrm{d}, 0.4 \mathrm{M} \mathrm{NaCl}$ in $50 \mathrm{mM}$ Tris-HCl, $\mathrm{pH} \mathrm{7.5).} \mathrm{Flow} \mathrm{rate}$ was $40 \mathrm{ml} / \mathrm{h}$ and $8-\mathrm{ml}$ fractions were collected. CS depolymerase activity was monitored by the N-acetylhexosamine assay with CS-A as substrate. Protein was determined by the Pierce protein assay: 9 , protein; $\square$, enzyme activity. 


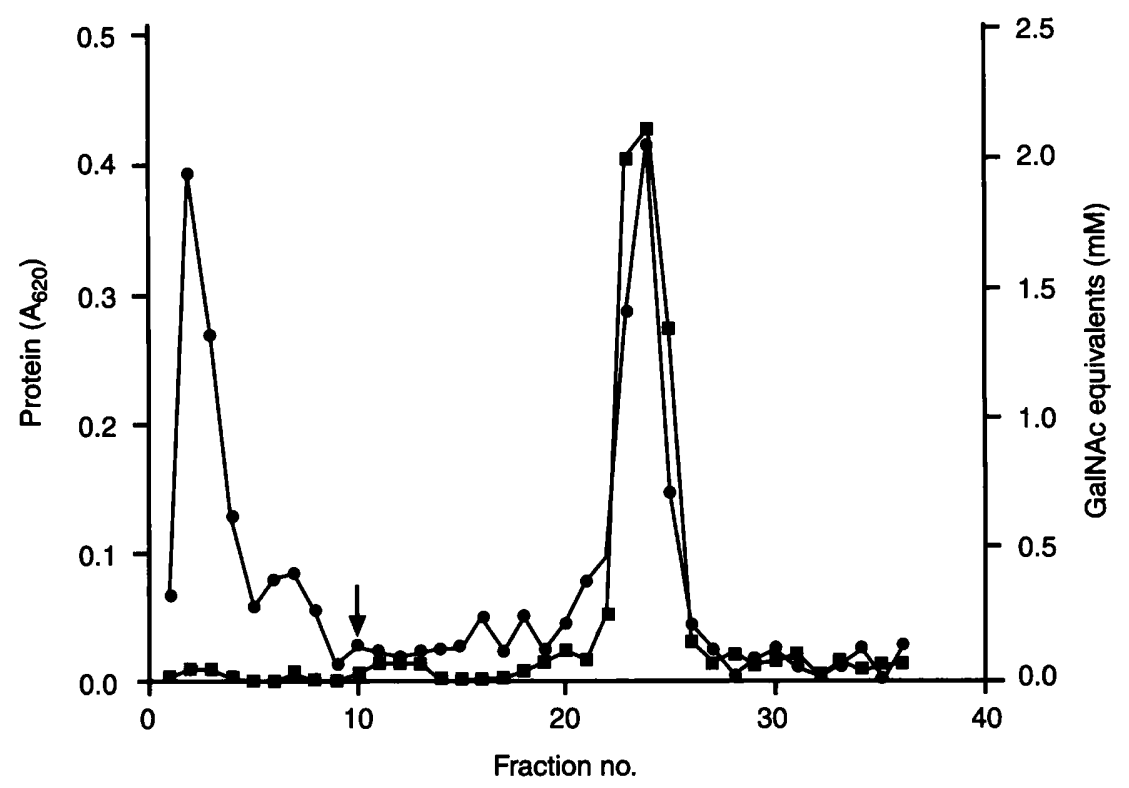

Fig. 2. Separation of GAG depolymerase on a $C M$ trisacryl $M$ column $(1.5 \times 24 \mathrm{~cm})$. Fractions of the second peak (shown in Fig. 1) from DEAE trisacryl $\mathrm{M}$ column were applied to $\mathrm{CM}$ trisacryl $\mathrm{M}$. Proteins were eluted with $50 \mathrm{mM}$ Tris- $\mathrm{HCl}, \mathrm{pH} 7.5$ (fractions 1-9) followed by application of a continuous salt gradient indicated by the arrow $(0-0.5 \mathrm{M}$ $\mathrm{NaCl}$ in $50 \mathrm{mM}$ Tris- $\mathrm{HCl}, \mathrm{pH} 7.5)$. Fractions $(8 \mathrm{ml})$ were collected and the flow rate was $40 \mathrm{ml} / \mathrm{h}$. $\mathrm{N}$-acetylhexosamine assay with CS-A and CS-C as substrates was used to determine enzyme activity and protein was determined by the Pierce protein assay: $\boldsymbol{O}$, protein; $\mathbf{\square}$, enzyme activity.

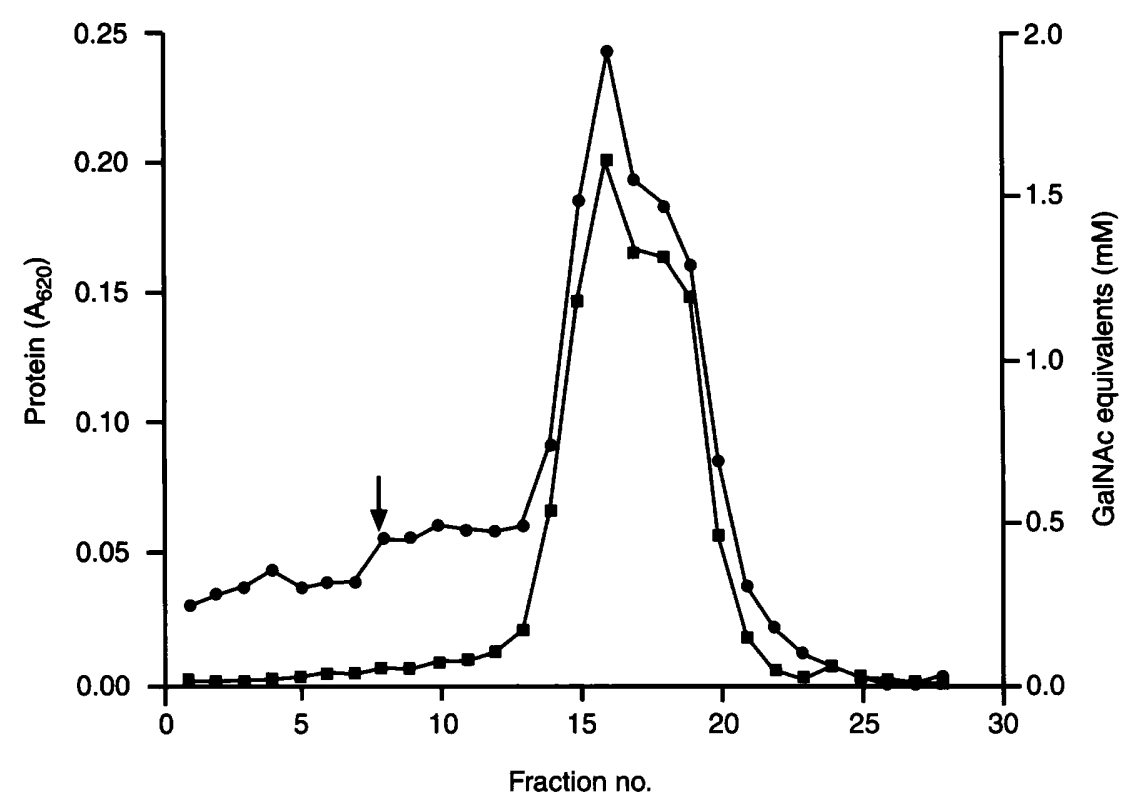

Fig. 3. Separation of GAG depolymerase on a heparin-agarose column $(1.5 \times 8.5 \mathrm{~cm})$. Fractions $1-7$ were eluted with

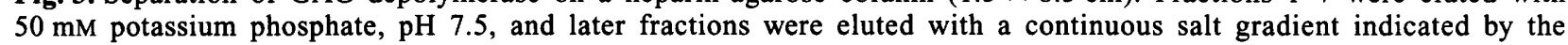
arrow $(0-0.5 \mathrm{M} \mathrm{NaCl}$ in $50 \mathrm{mM}$ potassium phosphate, $\mathrm{pH} 7.5)$. Fractions $(4 \mathrm{ml})$ were collected and the flow rate was $30 \mathrm{ml} / \mathrm{h}$. CS-C was used as substrate in the $\mathrm{N}$-acetylhexosamine assay and protein was measured with the Pierce protein assay $\mathbf{0}$, protein; $\mathbf{\square}$, enzyme activity.

\section{Protein estimation}

The protein concentration of the enzyme preparations at various stages of purification was determined routinely by a Coomassie Blue dye-binding assay (Sigma) in comparison with a standard curve of bovine serum albumin $(0-500 \mu \mathrm{g} / \mathrm{ml})$. The protein content of column fractions was monitored by a more sensitive Coomassie Blue dye-binding assay (Pierce) with bovine serum albumin $(0-20 \mu \mathrm{g} / \mathrm{ml})$ as standard.

\section{Mol. wt determination of purified CS depolymerase}

Before mol. wt determination by SDS-PAGE, a 3-ml sample of the enzyme preparation from the heparinagarose column was desalted and concentrated (Microsep Microconcentrator, $10 \mathrm{kDa}$ cut-off; Filtron Technology Corporation, MA, USA). To $5 \mu \mathrm{l}$ of the concentrated sample (protein concentration $82.3 \mu \mathrm{g}$ / $\mathrm{ml}), 10 \mu \mathrm{l}$ of sample buffer ( $10 \mathrm{mM}$ Tris- $\mathrm{HCl}, \mathrm{pH} 8.0$, 
$1 \mathrm{mM}$ EDTA, SDS $2.5 \%, \beta$-mercaptoethanol $5 \%$ ) was added and heated at $100^{\circ} \mathrm{C}$ for $5 \mathrm{~min}$. SDS-PAGE was performed with pre-formed homogeneous polyacrylamide $12.5 \%$ gels on the Phast system (Pharmacia Biotech, Uppsala, Sweden) with 1- $\mu$ l samples applied to the gels. A set of low mol. wt protein markers (Pharmacia) was used for mol. wt determination.

To separate the proteins, the Phast system was programmed with an initial low output $(100 \mathrm{~V}$, $1.0 \mathrm{~mA}, 1.0 \mathrm{~W}, 4 \mathrm{Vh}$ ) to draw samples through the stacking gel, followed by an increased output phase $(250 \mathrm{~V}, 3.0 \mathrm{~mA}, 3.0 \mathrm{~W}, 66 \mathrm{Vh})$ as described by Slayne et al. [21]. On completion of the electrophoretic separation the gel was transferred to the development chamber and stained by the silver staining protocol (Pharmacia).

The protein bands were visualised by high performance CCD video camera ( $\mathrm{COHU}$ ) and the image was captured with Bioscan Snapshot soft-ware (Datacell). The relative positions of the protein standards and the purified CS depolymerase were determined and the $\log _{10}$ mol.wt of the standard proteins were plotted against migration distance to calculate the mol. wt of the purified protein.

\section{Determination of isoelectric point ( $p I)$}

The $\mathrm{pI}$ of the CS depolymerase was determined using the Phast System (Pharmacia). A pH gradient was generated on a Phast Gel IEF 3-9 (Pharmacia) during a pre-focusing step $(2000 \mathrm{~V}, 2.5 \mathrm{~mA}, 3.5 \mathrm{~W}, 75 \mathrm{Vh})$. Following this, the enzyme ( $1 \mu 1$ each at both the anode and cathode positions) and $1 \mu \mathrm{l}$ of $\mathrm{pI}$ calibration kit proteins (broad range pI kit, Pharmacia) were applied. The voltage was reduced to $200 \mathrm{~V}$ during the application step. After the focusing step $(2000 \mathrm{~V}$, $2.5 \mathrm{~mA}, 3.5 \mathrm{~W}, 410 \mathrm{Vh}$ ), the proteins were visualised by silver staining as described by the manufacturer (Pharmacia). The pI of the depolymerase was determined by comparison with the relative positions of the calibration proteins, in the $\mathrm{pI}$ range 3-10.

\section{Determination of the pH optimum of the CS depolymerase}

The enzyme activity at various $\mathrm{pH}$ values was measured under the standard assay conditions by the
$\mathrm{A}_{232}$ method with $0.2 \mathrm{M}$ MES (2-[N-morpholino] ethane sulphonic acid) buffer (pH 5.5, 6.0,6.5), $0.2 \mathrm{M}$ sodium phosphate buffer $(\mathrm{pH} 6.5,7.0,7.5)$ and $0.2 \mathrm{M}$ Tris- $\mathrm{HCl}$ buffer $(\mathrm{pH} 7.5,8.0,8.5,8.9)$. The substrates used in the assays were CS-A and CS-C $10 \mathrm{mg} / \mathrm{ml}$ ) and hyaluronic acid (HA; Sigma; $5 \mathrm{mg} / \mathrm{ml}$ ).

\section{Determination of $K_{\mathrm{m}}$ and $V_{\max }$ values}

The $\mathrm{K}_{\mathrm{m}}$ and $\mathrm{V}_{\max }$ values were determined for the purified protein with CS-A, CS-C and HA as substrates from double reciprocal (Lineweaver-Burk) plots. The initial reaction velocities were measured at different substrate concentrations with a fixed enzyme concentration. A 1 in 50 dilution of the enzyme preparation was used for determining the $K_{m}$ and $V_{\max }$ values for HA. The rates of product formation were measured by the $\mathrm{A}_{232}$ assay and all assays were performed at the $\mathrm{pH}$ optimum of the enzyme.

\section{Substrate specificity of the CS depolymerase}

The substrates CS-A, CS-C, HA, heparin, heparan sulphate (Sigma), dermatan sulphate and keratan sulphate (Fluka Chemicals Ltd, Gillingham, Dorset) $(10 \mathrm{mg} / \mathrm{ml})$ were used to determine the substrate specificity of the purified enzyme. The assays were set up with $70 \mu \mathrm{l}$ of substrate, $20 \mu \mathrm{l}$ of the enzyme preparation and $50 \mu \mathrm{l}$ of $0.2 \mathrm{M}$ sodium phosphate buffer at $\mathrm{pH}$ 7.0. The reaction mixtures were incubated at $37^{\circ} \mathrm{C}$ for $2 \mathrm{~h}$ and the rate of substrate degradation was determined by monitoring the increase in $\mathrm{A}_{232}$.

\section{Results}

\section{Enzyme purification}

The CS depolymerase of $S$. intermedius strain UNS 35 was purifed to homogeneity by a combination of ammonium sulphate precipitation, ion exchange and affinity chromatography. Table 1 summarises the total activity, specific activity and recovery of the enzyme at each step of purification. An overall purification of 6.4-fold and a yield of $3.2 \%$ were obtained.

Earlier studies have indicated the inherent difficulties encountered in purifying bacterial CS depolymerases to homogeneity. Preliminary studies with crude

Table 1. Purification of GAG depolymerase from $S$. intermedius

\begin{tabular}{llllcc}
\hline Stage of purification & $\begin{array}{l}\text { Protein } \\
(\mathrm{mg})\end{array}$ & $\begin{array}{l}\text { Activity } \\
(\mu \mathrm{mol} / \mathrm{min})\end{array}$ & $\begin{array}{l}\text { Yield } \\
(\%)\end{array}$ & $\begin{array}{l}\text { Specific activity } \\
(\mu \mathrm{mol} / \mathrm{min} / \mathrm{mg})\end{array}$ \\
\hline Concentrated supernate & 24.9 & 96.6 & 100 & 3.8 & 1.0 \\
$\left(\mathrm{NH}_{4}\right)_{2} \mathrm{SO}_{4}$ precipitate & 13.7 & 54.7 & 56.0 & 4.0 & 1.0 \\
$\mathrm{DEAE}$ column & 1.528 & 24.4 & 25.3 & 16.0 & 4.2 \\
$\mathrm{CM}$ column & 0.690 & 13.4 & 13.9 & 19.4 & 5.1 \\
Heparin column & 0.125 & 3.1 & 3.2 & 24.5 & 6.4 \\
\hline
\end{tabular}


enzyme preparations obtained from the culture supernate of $S$. intermedius grown in minimal medium supplemented with CS-A indicated the presence of a sulphatase activity (with $\triangle \mathrm{UA}$ GalNAc-4S rather than $\triangle \mathrm{UA}$ GalNAc-6S as its preferred substrate) in addition to a CS-AC depolymerase (chondroitinase $\mathrm{AC}$ ) activity [39]. When these crude preparations were incubated with commercial CS-A (CS-A 70\%, CS-C 30\%) there was a progressive increase in the concentrations of $\triangle$ UA GalNAc-6S and $\triangle \mathrm{UA}$ GalNAc-OS, whereas that of $\triangle U A$ GalNAc-4S remained low during the incubation period due to the rapid desulphation of the latter disaccharide. The chemical assay for reducing $\mathrm{N}$ acetylhexosamine gives a positive reaction with $\triangle \mathrm{UA}$ GalNAc-6S (derived from CS-C) and $\triangle$ UA GalNAcOS but not with $\triangle \mathrm{UA}$ GalNAc-4S (derived from CSA) [18]. Therefore, when this assay is used to determine enzyme activity during the purification process with CS-A as the substrate, a strong positive reaction is indicative of the combined action of the depolymerase and the sulphatase. This assay was used to demonstrate indirectly the presence of the sulphatase and its subsequent removal during the protein purification process.

The enzyme of interest was prepared from $25 \mathrm{~L}$ of strain UNS 35 culture supernate; $56 \%$ of enzymicallyactive protein was precipitated from the concentrated culture filtrate by ammonium sulphate $80 \%$ precipitation. After dialysis, the enzyme preparation was fractionated by chromatography on a DEAE trisacryl $M$ column by step elution with increasing concentrations of $\mathrm{NaCl}$. A typical elution pattern is shown in Fig. 1. Fractions from the second peak, which eluted at $0.1 \mathrm{M} \mathrm{NaCl}$, showed the highest enzymatic activity. The strong positive results from the $\mathrm{N}$-acetylhexosamine assay described previously indicated that the enzyme preparation at this point still contained the sulphatase activity. These fractions were collected and subjected to further purification on a CM trisacryl $\mathrm{M}$ column. The enzymically active fractions eluted from the column as a single distinct protein peak (Fig. 2). Tests for enzyme activity with CS-A as substrate resulted in weak positive reactions with the $\mathrm{N}$-acetylhexosamine assay. When CS-C was substituted for CS-A, a three-fold increase in absorbance values at $\mathrm{A}_{540}$ was demonstrated, indicating that the enzyme preparation was free of contaminating sulphatase activity. However, SDS-PAGE analysis of the enzyme preparation at this stage demonstrated several contaminating protein bands (data not shown).

After ion-exchange chromatography the enzyme preparation was further purified with a heparin-agarose column. Fig. 3 shows the enzymically active fractions eluting as a single broad peak which corresponded with a distinct protein peak. This preparation was subsequently shown to be homogeneous by SDSPAGE.
Determination of protein purity, mol. wt and pI

SDS-PAGE analysis of the purified enzyme yielded a single band demonstrated by silver staining. The mol. wt of the enzyme was $c .83080$, as determined by comparison with SDS-PAGE protein mol. wt markers (Fig. 4). The purified protein was subjected to isoelectric focusing with proteins over the pI range 3.5-9.3 as standards. The purified CS depolymerase co-migrated with trypsinogen, indicating a $\mathrm{pI}$ of $c .9 .3$ (data not shown).

\section{pH optima of the CS depolymerase}

The purified enzyme was active against both CS-A and CS-C over a wide $\mathrm{pH}$ range $(6.0-8.0)$. Maximum activity against both substrates occurred at $\mathrm{pH} 7.0$, but

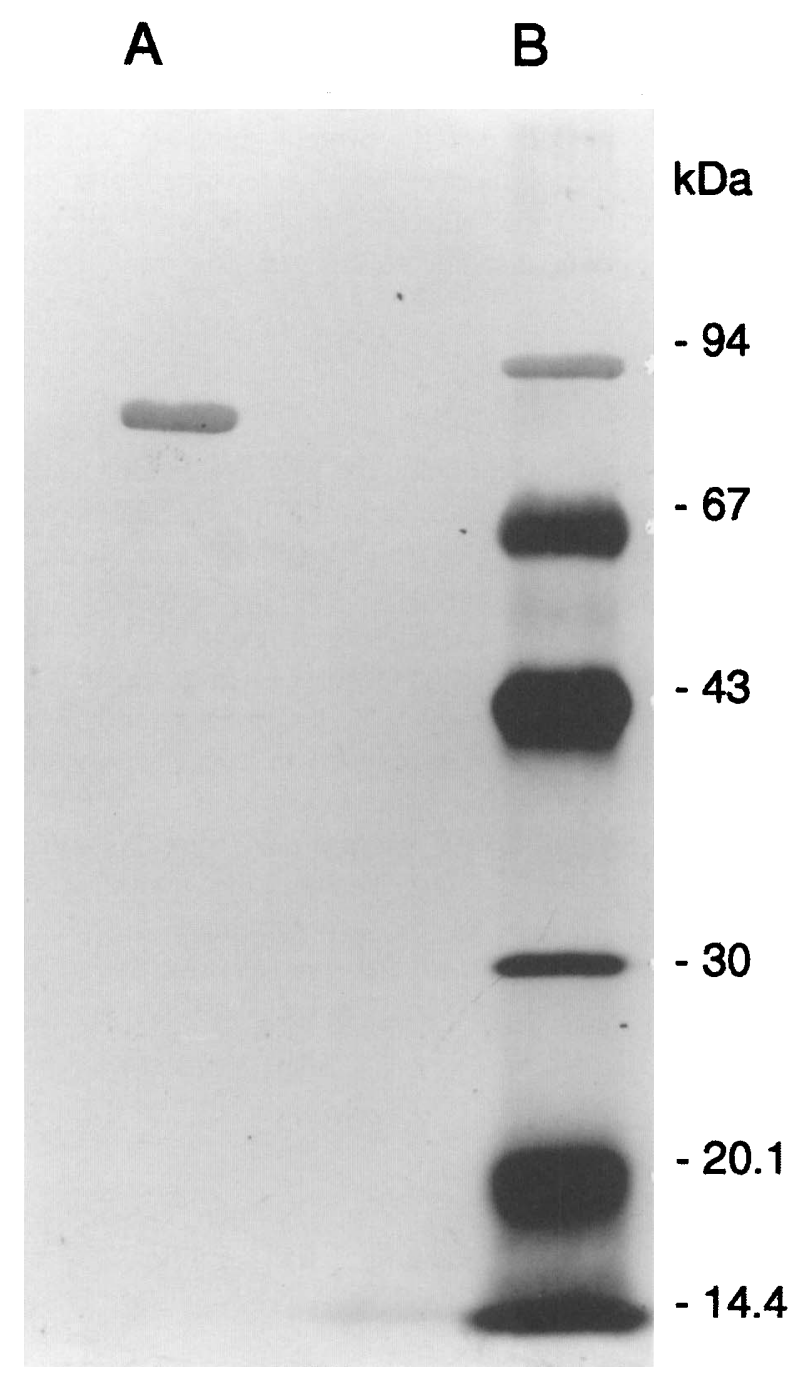

Fig. 4. SDS-PAGE (12.5\%) of the purified enzyme for $S$. intermedius (lane A) compared with the following marker proteins of known mol. wt (B): phosphorylase b (94 kDa); bovine serum albumin $(67 \mathrm{kDa})$; ovalbumin (43 kDa); carbonic anhydrase $(30 \mathrm{kDa})$; soybean trypsin inhibitor $(20.1 \mathrm{kDa})$; lactalbumin $(14.4 \mathrm{kDa})$. The gel was silver stained according to Pharmacia Phastgel silver kit protocol. 
with equal substrate concentrations the activity against CS-C was half that obtained with CS-A. The enzyme was highly active against $\mathrm{HA}$ over a $\mathrm{pH}$ range 6.5-8.0, with optimum activity at $\mathrm{pH} 7.5$ (Fig. 5).

$K_{\mathrm{m}}$ and $V_{\max }$ values

A study of the activity of the CS depolymerase against CS-A, CS-C and HA indicated that substrate degradation followed typical Michaelis-Menten kinetics. Lineweaver-Burk analysis of these data indicated that the $\mathrm{K}_{\mathrm{m}}$ values for CS-A, CS-C and HA were 26.6, 12.7 and $1.1 \mathrm{mg} / \mathrm{ml}$ respectively. The estimated $\mathrm{V}_{\max }$ for CS-A, CS-C and HA were $1.6,0.3$ and $19.5 \mu \mathrm{M} / \mathrm{min} / \mathrm{mg}$ of protein, respectively. The specificity constants $\left(\mathrm{V}_{\max } /\right.$ $\mathrm{K}_{\mathrm{m}}$ ) for the three substrates were 0.06 (CS-A), 0.03 (CS-C) and 17.0 (HA).

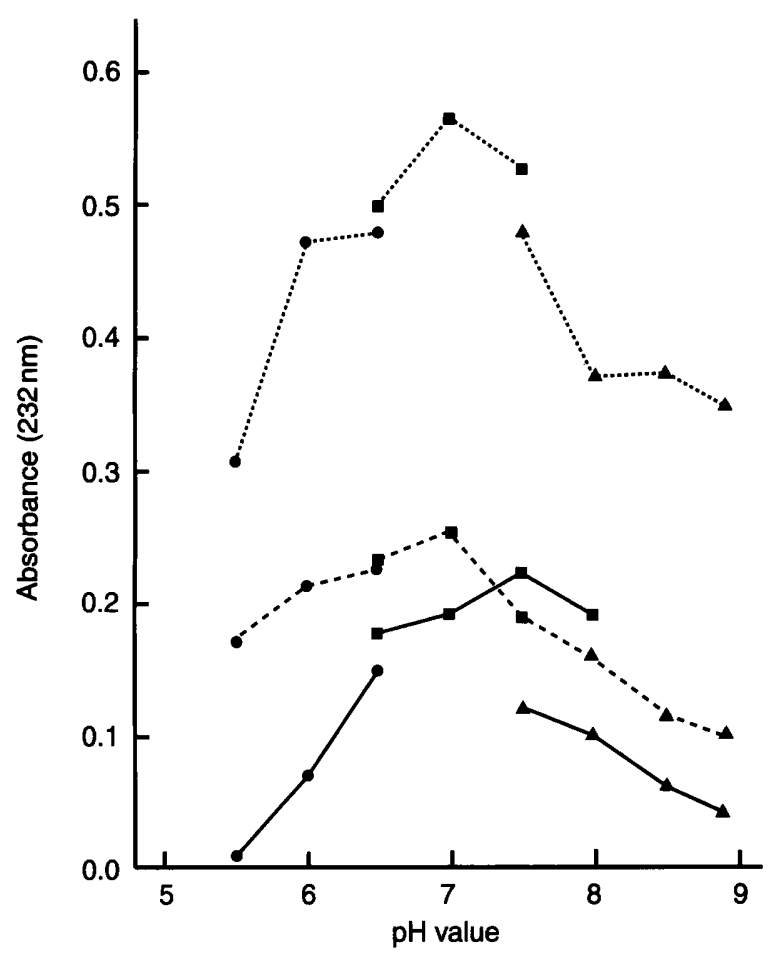

Fig. 5. pH optima for the degradation of various GAGs by the purified enzyme. The enzyme activity was measured in the standard reaction mixture with $0.2 \mathrm{M}$ MES (pH 5.5, 6.0 and 6.5; ); $0.2 \mathrm{M}$ sodium phosphate buffer (pH 6.5, 7.0, 7.5 and 8.0 for hyaluronic acid; $\square$ );

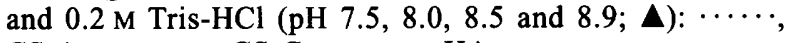
CS-A; - - - CS-C; - HA.

Table 2. Comparative activities of the purified enzyme against glycosaminoglycans

\begin{tabular}{lc}
\hline Substrate & Relative activity (\%) \\
\hline Hyaluronic acid & 100 \\
CS-A & 7.7 \\
CS-C & 5.6 \\
Dermatan sulphate & 1.4 \\
Keratan sulphate & $<0.01$ \\
Heparan sulphate & $<0.01$ \\
Heparin & $<0.01$ \\
\hline
\end{tabular}

\section{Substrate specificity}

The enzyme was most active against HA and exhibited less activity towards CS-A, CS-C and dermatan sulphate (Table 2). Activity against keratan sulphate, heparan sulphate and heparin could not be detected.

\section{Discussion}

Bacterial GAG depolymerases differ from the mammalian equivalents in that they cleave GAGs by an elimination reaction leading to the production of 4,5unsaturated disaccharides $[18,22,23]$. The chondroitinase ABC produced by Proteus vulgaris [18] and Bacteroides thetaiotaomicron [20] degrades primarily CS-A, CS-B (dermatan) and CS-C, with little activity against HA ( $10 \%$ of chondroitinase activity). Flavobacterium heparinum produces three distinct enzymes, each with CS depolymerising activity: chondroitinase $\mathrm{AC}$ which is equally active against CS-A and CS-C but also has some activity against HA $(20 \%$ of the chondroitinase activity) [18]; chondroitinase $\mathrm{C}$ which shows equal activity against CS-C and HA [24]; and chondroitinase B which acts specifically on CS-B [25]. Except for the chondroitinase $\mathrm{AC}$ of $F$. heparinum which is constitutive [18], the other reported chondroitinases are induced by growing the organisms in the presence of the appropriate CS. A chondroitinase C from $S$. intermedius has been partially purified but its activity on HA was not reported [26].

The GAG depolymerases of $S$. intermedius UNS 35 exhibited an unusual substrate specificity. It depolymerised HA rapidly and acted on CS-A and CS-C at about $8 \%$ and $2 \%$, respectively, of the rate with HA. Although the $\mathrm{K}_{\mathrm{m}}$ for the CS-A was twice that observed for CS-C, comparison of $V_{\max }$ and specificity constants $\left(\mathrm{V}_{\max } / \mathrm{K}_{\mathrm{m}}\right)$ confirmed that, of the two sulphated GAGs, CS-A is the preferred substrate (the $\mathrm{V}_{\max }$ value for CS-A was approximately five-fold greater than that for CS-C). However, the specificity constant for HA is c. 280 -fold greater than that for CS-A and on the basis of this unusual substrate specificity the depolymerase activity would best be classified as a hyaluronidase rather than a CS depolymerase. Of the bacterial chondroitinases previously purified, the chondroitinase $\mathrm{C}$ of $F$ heparinum has similar properties to the depolymerase reported here in that it is induced by CS but has slightly greater activity against HA than CS-C, based on the relative amount of disaccharides produced. It was suggested that this enzyme chondroitinase $C$, could be classified as a hyaluronidase type II $\mathrm{C}$ following the nomenclature proposed by Gibian [27].

GAG depolymerases that act mainly on HA have been purified from streptococci [28-30], pneumococci [31], Staphylococcus aureus, [32], clostridia [33], Escherichia freundii [34] and peptostreptococci [35]. The bacterial hyaluronidases have mol. wts of 55000 
160000 with an optimal $\mathrm{pH}$ range of 5.6-6.6 and $\mathrm{pl}$ values in the region of $\mathrm{pH} 5.0-6.0$. The GAG depolymerase purified from $S$. intermedius is similar to the peptostreptococcal hyaluronidase in that it is more active around a neutral $\mathrm{pH}$ [35]; however, it is unique in having a high isoelectric point.

Multiple molecular forms of GAG depolymerases have been described for Staph. aureus [32], B. thetaiotaomicron [20] and $F$. heparinum $[18,24,25]$. S. intermedius UNS 35 grown in medium supplemented with CS-A has been shown to produce both hyaluronidase and CS depolymerase activities [36,37] but whether the GAG depolymerase reported here is responsible for both activities or whether they are distinct enzymes has not been ascertained.

In mammalian tissues, CS-C is less susceptible to hyaluronidase degradation than CS-A; this is a poorer substrate for hyaluronidase than HA. Despite these observations, degrading activities of CS in mammalian tissues have been attributed to the combined actions of hyaluronidase and exo-enzymes including glycosidases and O-sulphatases [38]. Bacterial chondrosulphatases differ from mammalian $\mathrm{O}$-sulphatases by their activity on sulphated 4,5-unsaturated disaccharides and do not act on longer oligosaccharides [18]. S. intermedius UNS 35 produces a sulphatase with $\triangle$ UA GalNAc-4S (derived from CS-A) rather than $\triangle U A$ GalNAc-6S (derived from CS-C) as its preferred substrate [39], forming the desulphated disaccharide, $\triangle U A$ GalNAc$\mathrm{OS}$; this is subsequently catabolised by $S$. intermedius grown in batch culture. Although the GAG depolymerase produced by $S$. intermedius has greater hyaluronidase activity than CS depolymerase activity, on the basis of the mammalian model of CS degradation, it seems reasonable to propose that it is its ability to produce a sulphatase activity that enables $S$. intermedius to degrade CS-A and utilise the resulting desulphated disaccharide ( $\triangle \mathrm{UA}$ GalNAc-OS) as a source of nutrient. This would explain our invitro observations that the organism can grow in minimal medium supplemented with CS-A as the sole carbohydrate source.

\section{References}

1. Parker MT, Ball LC. Streptococci and aerococci associated with systemic infection in man. $J$ Med Microbiol 1976; 9: 275-302.

2. Ball LC, Parker MT. The cultural and biochemical characters of Streptococcus milleri strains ioslated from human sources. J Hyg 1979; 82 63-78.

3. Poole PM, Wilson G. Occurrence and cultural features of Streptococcus milleri in various body sites. J Clin Pathol 1979; 32: 764-768.

4. Shlaes DM, Lerner PI, Wolinsky E, Gopalakrishna KV. Infections due to Lancefield group $\mathrm{F}$ and related streptococci (S. milleri, S. anginosus). Medicine 1981; 60: 197-207.

5. Murray HW, Gross KC, Masur H, Roberts RB. Serious infections caused by Streptococcus milleri. Am J Med 1978; 64: 759-764.
6. Anonymous. Streptococcus milleri, pathogen in various guises. Lancet 1985; 2: 1403-1404.

7. Ruoff KL. Streptococcus anginosus ("Streptococcus milleri"): the unrecognized pathogen. Clin Microbiol Rev 1988; 1: 102 108.

8. Piscitelli SC, Shwed J, Schreckenberger P, Danziger LH. Streptococcus milleri group: renewed interest in an elusive pathogen. Eur J Clin Microbiol Infect Dis 1992; 11: 491-498.

9. Whiley RA, Beighton D. Emended descriptions and recognition of Streptococcus constellatus, Streptococcus intermedius, and Streptococcus anginosus as distinct species. Int J Syst Bacterial 1991; 41: 1-5.

10. Unsworth PF. Hyaluronidase production in Streptococcus milleri in relation to infection. J Clin Pathol 1989; 42 506510.

11. Whiley RA, Fraser H, Hardie JM, Beighton D. Phenotypic differentiation of Streptococcus intermedius, Streptococcus constellatus, and Streptococcus anginosus strains within the "Streptococcus milleri group". J Clin Microbiol 1990; 28: 1497-1501.

12. Whiley RA, Beighton D, Winstanley TG, Fraser HY, Hardie JM. Streptococcus intermedius, Streptococcus constellatus, and Streptococcus anginosus (the Streptococcus milleri group): association with different body sites and clinical infections. $J$ Clin Microbiol 1992; 30: 243-244.

13. Beighton D, Hardie JM, Whiley RA. A scheme for the identification of viridans streptococci. J Med Microbiol 1991; 35 367-372.

14. Kjellen L, Lindahl U. Proteoglycans: structures and interactions. Annu Rev Biochem 1991; 60: 443-475.

15. Levvy GA, McAllan A. The N-acetylation and estimation of hexosamines. Biochem $J$ 1959; 73: 127-132.

16. Homer KA, Patel R, Beighton D. Effects of N-acetylglucosamine on carbohydrate fermentation by Streptococcus mutans NCTC 10449 and Streptococcus sobrinus SL-1. Infect Immun 1993; 61: 295-302.

17. Saito H, Yamagata T, Suzuki S. Enzymatic methods for the determination of small quantities of isomeric chondroitin sulfates. J Biol Chem 1968; 243: 1536-1542.

18. Yamagata T, Saito H, Habuchi O, Suzuki S. Purification and properties of bacterial chondroitinases and chondrosulphatases. $J$ Biol Chem 1968; 243: 1523-1535.

19. Russell RRB. Comparison of oral Streptococcus mutans AHT with strains of serotypes $a$ and $g$ by biochemical and electrophoretic methods. Arch Oral Biol 1979; 24; 617619.

20. Linn S, Chan T, Lipeski L, Salyers AA. Isolation and characterization of two chondroitin lyases from Bacteroides thetaiotaomicron. J Bacteriol 1983; 156: 859-866.

21. Slayne MA, Aldred MJ, Wade WG. A rapid, semi-automated SDS-PAGE identification system for oral anaerobic bacteria. J Appl Bacteriol 1990; 68: 391-395.

22. Linker A. Bacterial mucopolysaccharidases (mucopolysaccharide lyases). Methods Enzymol 1966; 8: 650-654.

23. Tipler LS, Embery G. Glycosaminoglycan-depolymerising enzymes produced by anaerobic bacteria isolated from the human mouth. Arch Oral Biol 1985; 30: 391-396.

24. Michelacci YM, Dietrich CP. Chondroitinase C from Flavobacterium heparinum. J Biol Chem 1976; 251: 1154-1158.

25. Michelacci YM, Dietrich CP. Isolation and partial characterization of an induced chondroitinase B from Flavobacterium heparinum. Biochem Biophys Res Commun 1974; 56: 973-980.

26. Hibi E, Osano E, Fujii Y, Moriyama T. Chondroitinase C activity of Streptococcus intermedius. FEMS Microbiol Let 1989; 57: 121-124.

27. Gibian $\mathrm{H}$. Enzymes degrading glycosaminoglycans. In: Balazs EA, Jeanloz $R$ (eds) The amino sugars, vol $2 \mathrm{~B}$, Metabolism and interactions. New York, Academic Press. 1966: 181-200.

28. Hill J. Purification and properties of streptococcal hyaluronate lyase. Infect Immun 1976; 14: 726-735.

29. Hamai A, Morikawa K, Horie K, Tokuyasu K. Purification and characterization of hyaluronidase from Streptococcus dysgalactiae. Agric Biol Chem 1989; 53: 2163-2168.

30. Sting R, Schaufuss $\mathrm{P}$, Blobel $\mathrm{H}$. Isolation and characterization of hyaluronidases from Streptococcus dysgalactiae, S. zooepidemicus and S. equi. Int J Med Microbiol 1990; 272: 276-282.

31. Linker A, Meyer K, Hoffman P. The production of unsaturated uronides by bacterial hyaluronidases. J Biol Chem 1956; 219 : 13-25. 
32. Abramson C. Staphylococcal hyaluronidase isoenzyme profiles related to Staphylococcal disease. Ann NY Acad Sci 1974; 236: 495-507.

33. Kennedy JF. Enzymic susceptibilities of glycosaminoglycans and proteoglycans. In: Proteoglycans-biological and chemical aspects in human life. (Studies in organic chemistry 2) Amsterdam, Elsevier Scientific Publishing Company. 1979: 195-223.

34. Brunish R, Mozersky SM. The characterization of hyaluronidase isolated from Escherichia freundii. J Biol Chem 1958; 231: $291-301$.

35. Tam Y-C, Chan ECS. Purification and characterization of hyaluronidase from oral Peptostreptococcus species. Infect Immun 1985; 47: 508-513.

36. Homer KA, Denbow L, Whiley RA, Beighton D. Chondroitin sulfate depolymerase and hyaluronidase activities of viridans streptococci determined by a sensitive spectrophotometric assay. J Clin Microbiol 1993; 31: 1648-1651.

37. Homer KA, Grootveld MC, Hawkes J, Naughton DP, Beighton D. Degradation of hyaluronate by Streptococcus intermedius strain UNS 35. J Med Microbiol 1994; 41: 414-422.

38. Rodén L. Structure and metabolism of connective tissue proteoglycans. In: Lennarz WJ (ed) The biochemistry of glycoproteins and proteoglycans. New York, Plenum Press. $1980267-371$.

Reference added in proof:

39. Shain H, Homer KA, Beighton D. Degradation and utilisation of chondroitin sulphate by Streptococcus intermedius. $\mathrm{J}$ Med Microbiol 1996; 44: 372-380. 